\title{
DIVIDEND PAYOUT, RETENTION POLICY AND FINANCIAL PERFORMANCE IN COMMERCIAL BANKS: ANY CAUSAL RELATIONSHIP?
}

\section{Odunayo Magret OLAREWAJU*}

Durban University of Technology, South Africa

\section{Stephen Oseko MIGIRO}

University of KwaZulu-Natal, South Africa

\section{Mabutho SIBANDA}

University of KwaZulu-Natal, South Africa

\begin{abstract}
Dividend policy remains one of the top ten unresolved issues in corporate finance including in the banking sector. Hence, this study explores data from 250 commercial banks in 30 Sub-Saharan African countries to establish the causal relationship between the use of two major dividend policies in the sector and financial performance for the period 2006 to 2015. The empirical results of the vector error correction block exogeneity Wald test and Pairwise Granger causality test reveal that only retention policies Granger cause performance (ROA), even though both major policies posit a positive relationship with performance (ROA) in the Vector Error Correction Model estimate. Therefore, commercial banks in Sub Saharan Africa and also in the entire world should use their free cash flows wisely by exploring all available viable investment opportunities. By doing this, not only owners' profit but wealth is fully maximised such that their survival, value creation, and future growth is fully justified.
\end{abstract}

JEL classification: G21, G35.

Keywords: Retention policy; Wald test; Granger causality; Stakeholders' interest; Creditors' right; Wealth maximisation.

\footnotetext{
* Corresponding author Address: Department of Management Accounting, Faculty of Accounting and Informatics, Ritson Campus, Durban University of Technology, 7 Ritson Road, Durban, South Africa. Email:odunayoo@dut.ac.za
} 


\section{Introduction}

Dividend policy has attracted attention following the seminal paper of Miller and Modigliani (1961) where they established that dividend policy has no effect on shareholders' wealth in a frictionless and perfect market with investment policy being held constant. This prediction has led to an ongoing debate and a dilemma as to how firms should choose a suitable and implementable policy. This dilemma is even deeper in Sub-Saharan African countries because there is no perfect market condition as proposed by Miller and Modigliani. There have been a wide number of ideas by economists and past scholars proffering solutions to this dilemma. A popular solution is the proposed signalling approach, that is, the choice of dividend policy to signal future firm performance. This solution has been initially supported empirically by scholars such as Ajanthan (2013), Karpavičius (2014), Abiola (2014), Abdella and Manual (2016), Adesina (2017), Agbatogun and Adewumi (2017) but recently, the results have been mixed such that some scholars find that dividend changes do not predict future earnings growth in firms (Datta, Ganguli, \& Chaturvedi, 2014; David \& Ginglinger, 2016).

The other idea for solving the dividend dilemma which has been given little or no attention, most importantly in the banking sector, is the agency approach to dividend policy, meaning that dividend policy minimises the conflict of interest that leads to agency problems in any firm operating agency relationships. According to S. Gul, Sajid, Razzaq, and Afzal (2012), agency conflicts that lead to agency cost can manifest in two ways: debt-holders versus shareholders conflict (agency cost of debt) and managers versus shareholders conflict (agency cost of equity). In the shareholdersmanagers' relationship, ceteris paribus, managers are more interested in a retention policy because of their personal pecuniary benefits and all other compensations attached. This personal interest will invariably increase a managers' flexibility, maximise the asset size and reduce the need to raise funds from the capital market to finance long-term projects, all of which are against the interests of the shareholders. Although shareholders desire managerial efficiency in viable and positive net present value (NPV) investment decisions, they prefer their managers to fund such investment from the capital market with little cash in managements' purse to avoid managers acting against the owners' sole interest. Shareholders believe the capital market performs a monitoring role regarding the activities of managers and ensures higher managerial discipline. Thus, for banks to operate fully in their desired capacity and performance, an optimal dividend policy that will minimise these costs must be implemented because both agency cost affects bank performance (Shao, Kwok, \& Guedhami, 2013).

To the advocate of retention, firms' earnings should be used to finance investment in positive NPV projects, which are expected to bring about an improvement in the performance of firms. Retained earnings are considered as a better and cheaper source of finance than raising funds from external sources, which are associated with exorbitant costs. The majority of empirical studies have focused on examining the impact of dividend policy on performance or testing the relationship or correlation between dividend policy and a firm's performance (Ehikioya, 2015; Hamid, Yaqub, \& Awan, 2016). Correlation/relationship does not necessarily imply causation. Akinlo and Egbetunde (2010) believed it is meaningful to test for causation as opposed to correlation as causation shows the cause and effect relationship between variables. Regarding this aspect, scholars such as Farsio, Geary, and Moser (2004), Goddard, McMillan, and 
Wilson (2006) and Mougoué and Rao (2003) have tested for cointegration and causality tests of dividend payout and earnings, taking dividend payout as the only dividend policy and neglecting the retention policy of dividend even though it is not in Africa or Sub-Saharan African (SSA) region.

Apparently, payout and retention are two sides (types) of a coin (dividend policy). It is noteworthy that virtually all studies on the subject have used dividend payment or payout (not retained earnings) as a proxy for dividend policy. It can also be observed that the studies above neither consider causality between retained earnings and firms' financial performance nor were they carried out in the SSA region. It is imperative to conduct empirical studies on the direction of causality between dividend policies (both retained earnings and dividend payout) and the financial performance of banks in SSA countries. This study is an attempt in that direction.

Nnadi, Wogboroma, and Kabel (2013) posit that most African firms, banks inclusive, prefer to payout cash dividend. The choice of dividend payout as against dividend reinvestment plans is the uncertainty about how investors utilise earnings generated by managers. However, it is possible that earnings are generated from vague activities that managers dabble in to make sure dividends are paid to satisfy the desire of dividend-income oriented shareholders even though such activities cannot guarantee the future growth of the firm. The present weaknesses of SSA banks as noted by Mlachila et al. (2013), such as weak creditor's right, poor infrastructure, low bank's asset, poor financial depth calls for urgent investigation on dividend policy as this policy affects other policies in the bank. Therefore, this study finds it necessary to weigh the two policies; namely payout (a bird in the hand) and retention (a bird in the bush), because it is possible for managers to engage in dividend re-investment plans, which are well monitored such that the bird does not fly away, and to assure the investors of huge and certain capital gains. More so, investors have clientele effects while some are dividend-income oriented, others are not in need of income but are growth-oriented.

It is in this regard that Shao et al. (2013) and Byrne and O'Connor (2017) posit that both creditors and shareholders' interest should be protected in making dividend policy because dividend payment lowers owners' apprehensions about managers' expropriation but exacerbate creditors' apprehensions about owners' expropriations. Hereafter, the use of dividend payout to proxy dividend policy in most studies and lack of studies to address causality between dividend policy and bank performance despite the perpetual debate as to which policy to adopt such that banks' future growth is justified foretells our interest to investigates the causal relationship between both dividend policies (payout and retention) and banks' financial performance in the SSA. Although numerous studies focused on the feedback relationship between dividend policy and performance, this study answers the question insufficiently approached: which of the two dividend policies causes increment in bank value and performance?

The remainder of this paper is structured following the introductory section as follows: the section two focuses on the theoretical background aspect of the literature review, followed by the research method in section three. The model estimation is captured in section four and the paper is concluded with policy recommendations in section five. Conclusively, the last section shows the limitations of this study and suggests further areas of research for the would-be researchers. 


\section{Literature Review}

This study is underpinned by the Percent payout and Percent retention theories of dividend. These theories were propounded by Rubner (1966). For percent payout theory, its basic proposition is that shareholders prefer dividend income and hence firms should adopt payout policy amidst many other dividend policies. Managers are expected to convince investors that their expected return on investment will increase their current wealth. However, for managers to ensure their job security and maintain a good reputation with shareholders, they should adopt a 100 percent payout policy. This is despite that fact that this may not be practicable if managers are pursuing maximisation of all owners' wealth. Careful evaluation will be required if the business model is faltering; if the company needs funding to undertake a specific project that will enhance its long term growth; and if the firm's growth is slowing down due to competition or other factors.

On the other hand, percent retention theory argues that, since investors fall into different categories such as income, age, tax bracket, etc, managers should adopt a 100 percent retention policy so as to avoid conflict between shareholders, minimise the burden of the high tax (double taxation) attracted by dividend income and reduce the transaction costs associated with a payout policy which have made the policy a luxury, and negative NPV transactions. Under this theory, firms should take up all viable investment opportunities as positive NPV transactions which will assist in achieving the ultimate corporate goal (maximisation of shareholders' wealth).

\section{Methodology: research design, data nature and sources}

This study is based on an unbalanced panel of 250 commercial banks from 30 SSA countries. Panel data was used to cater for the heterogeneity problem that the individual bank characteristics might cause (Hsiao, 2014). Not all the data required to capture the variables of interest were available for the entire SSA countries for the study period, hence it was unbalanced. Therefore, annual/ yearly data were collected from 250 commercial banks' financial profile with up-to-date data available in BankScope database by Fitch/ IBCA Bureau Van Dijk covering the period 2006 to 2015. As recently noted by Beck, Demirgüç-Kunt, and Maksimovic (2004), Houston, Lin, Lin, and Ma (2010), Akande and Kwenda (2017), when conducting research with focus on banking sector, BankScope is considered as the most reliable, comprehensive and appropriate database because it accounts for over $90 \%$ of all country's banklevel data. The fact that data was sourced from this reputable database justifies the reliability of the data used for this study. The SSA countries considered in this study excludes those regarded as outliers such as South Africa and Mauritius due to their highly competitive and sophisticated banking system (Beck \& Cull, 2013). Also, countries such as such as democratic republic of Congo, Comoros, Guinea-Bissau, Sao Tome and Principle and others with lack of data due to the effect of war were excluded because of dearth and the paucity of data (Akande \& Kwenda, 2017; Flamini, Schumacher, \& McDonald, 2009). Succinctly, the countries used are Angola, Burkina Faso, Benin, Botswana, Cote d' Ivoire, Cameroon, Ethiopia, Gabon, Ghana, Djibouti, Equatorial Guinea, Kenya, Lesotho, Liberia, Madagascar, Mali, Mauritania, Malawi, 
Mozambique, Namibia, Niger, Nigeria, Rwanda, Seychelles, Senegal, Swaziland, Togo, Tanzania, Uganda and Zambia. These countries are bank-based economies in which commercial banking constitute more than $70 \%$ of their financial system asset on the average. They are impoverished and operate under unique economic and banking conditions characteristics such as weak creditors right, underdeveloped/ critical infrastructural facilities, high inflation, poverty, external shocks, high concentration, shallow financial system and non-adherence to the global regulatory requirements in detail (Akande \& Kwenda, 2017; Allen et al., 2014; Flamini et al., 2009).

The validity of the variables and data used in this study is based on the previous empirical studies on dividend policy. All the variables were used based on the fact that scholars have used them and affirmed that they are valid in proxying dividend policy (Abdella \& Manual, 2016; Agyemang Badu, 2013; Ehikioya, 2015; Ibrahim, 2016). Return on asset (ROA) is used in this study as a measure of bank performance because ROA shows the overall index of profitability (Crane, 2010). Also, capital adequacy was used a control variable to avoid simultaneity bias that can be caused by bivariate causality model and the fact that adequate capital is the basis for making any policy in the banking sector (Nnadi et al., 2013).

Model Specification: To establish the causality between dividend policy and bank performance, the Percent payout and Percent retention theory of dividends are the theories underpinning this study. It has been affirmed that dividend payment can be a luxury due to high taxation and other transaction costs attracted by dividends if the life span of the firm is not considered. For the banking sector, dividend payouts have been treated as a norm, which might be the reason behind their recurrent underdevelopment (Nnadi et al., 2013); hence, a firm if well monitored can also retain and re-invest in new investment opportunities that would protect the stakeholders' interest (shareholders, debtholders and depositors) and yield greater return with little or no transaction costs (Ashraf \& Zheng, 2015).

Theories such as "a bird in the hand", the signalling hypothesis and the empirical findings of Agyei and Marfo-Yiadom (2011) and Hamid et al. (2016) have asserted the feedback relationship between dividend policy and performance.

Therefore;

$$
Y=f(X) .
$$

That is,

Performance $=f$ (Dividend policy)

According to Waseem, Saleh, Shukairi, and Mahmood (2011), dividend policy is unstable in the banking sector, but there are two commonly adopted dividend policies in the banking sector: namely, the dividend payout policy and the dividend re-investment plan (Retention Policy).

Hence,

Performance $=f$ (Dividend payout ratio, Retention ratio)

To avoid omission and germane variables that can lead to simultaneity bias, capital adequacy ratio is included as a control variable. Capital adequacy ratio is considered because all the banking acts of the 30 countries considered for this study 
have in their guidelines that banks should declare and pay dividends only when the minimum capital adequacy ratio has been met. Thus, in choosing a suitable and implementable dividend policy that will positively affect performance in the banking sector, the Basel capital framework laid down that capital and a conservation buffer ratio must be taken into consideration.

Performance $=\mathrm{f}$ (Dividend payout ratio, Retention ratio, Capital adequacy ratio)

Following the empirical literature of Crane (2010), who posited that Return on asset (ROA) is the measure of the return on a firm's assets which shows the overall index of profitability, ROA has been used to measure financial performance so as to be able to proffer solutions to the yearly debate as to which policy can actually impact on bank performance and this justifies the choice and validity of ROA in this study. Thus, explicitly the model for this study is:

$$
Y_{i t}=\beta_{0}+\beta_{1} X_{i t}^{\prime}+R_{i t}+u_{i t}
$$

$X_{i t}^{\prime}$ is the vector of banks dividend policy captured by the payout and retention ratio

$R_{\text {it }}$ captures the control variable, capital adequacy ratio

$R O A_{i t}=f\left(D P O R_{i t}, R E R A_{i t}, C A R_{i t}\right)$

$R O A_{i t}=\beta_{0}+\beta_{1} D_{P O R_{i t}}+\beta_{2} R E R A_{i t}+\beta_{3} C A R_{i t}+u_{i t}$

All variables are in their natural form.

$\beta_{1}, \beta_{2}$ and $\beta_{3}$ are the estimated parameters of the respective explanatory variables which show the percentage change in financial performance caused by the percentage change in the explanatory variables. $\beta_{0}$ is the intercept/constant term.

For easy understanding and interpretation of the model, the variables used in the model are clearly defined below;

Return on Assets (ROA): This measure of performance indicates how profitable a bank is with respect to its total assets. This ratio points to how bank management is at using its total assets component to generate earnings. It was calculated as $\frac{\text { Profitaftertax }}{\text { TotalAsset }} * 10 \mathrm{C}$. The ratio has been used by various scholars to measure TotalAsset

performance, including Ouma (2012), Agyei and Marfo-Yiadom (2011), Onanjiri and Korankye (2014b) and Ehikioya (2015).

Dividend Payout Ratio (DPOR): This represents the payout policy of dividends in banks. The data point is in percentage form and data are sourced from the BankScope database. The formula is $\frac{\text { Totaldividend }}{\text { TotalEarnings }} * 100$. This variable has been used by Agyei and Marfo-Yiadom (2011), Nnadi et al. (2013), Agyemang Badu (2013) and Maldajian and El Khoury (2014) because it shows the proportion of dividend paid out. 
Retained Earnings Ratio (RERA): This represents the retention policy of dividends in banks. The data point is in percentage form and the data for the variables used as proxy are sourced from the BankScope database. The formula is $\frac{\text { Retainedearnings }}{\text { TotalEarnings }} * 100$

This variable has been used by previous dividend policy study conducted by Hamid et al. (2016). It is also fondly called financial slackness.

Capital Adequacy Ratio (CAR): This is the ratio of total equity to total assets. Its data point is in percentage form and the data for the variables are sourced from the BankScope database. The formula is $\frac{\text { Totalequity }}{\text { Totalasset }} * 100$ It has been used in studies such as Al-Ajmi (2010) and Nnadi et al. (2013) among many others.

Estimating Technique: The panel Granger causality test is used to test the direction of causality between bank performance and dividend policy, taking a cue from the three evident studies on dividend policy causality, namely, Mougoué and Rao (2003), Farsio et al. (2004) and Goddard et al. (2006) and other studies that have used panel Granger causality (Chang, Lee, \& Chang, 2014; Wolde-Rufael, 2014). The Granger causality test showed that if past values of dependent variable $(Y)$ significantly contribute to predicting the value of an explanatory variable $(X)$, then $Y$ Granger causes $X$, and vice versa, but if the past values of both variables contribute significantly to predict each other, it leads to bi-directional causality. The rationale of Granger causality in this model is that changes in dividend policy Granger cause changes in bank performance if the changes in dividend policy improved the unbiased least square forecast of the changes in bank performance. The null hypothesis $\left(\mathrm{H}_{0}\right)$ is that dividend policy does not Granger cause bank performance and bank performance does not granger cause dividend policy. Pairwise Granger causality and the Granger causality test from vector error correction block exogeneity Wald test is used to establish both the short- and longrun uni-directional or bi-directional causality between the pairs of variables.

The Panel-VEC model is;

If $Y_{i t}=\left(Y_{1 i t}, Y_{2 i t}, Y_{3 i t}, \ldots \ldots \ldots \ldots . . . Y_{\text {qit }}\right)$ is a $q \times 1$ vector of cross-sections $i$ in time $t$

$Y_{i t}=\delta_{i} b_{t}+\sum_{k=1}^{m} \Phi_{i k} Y_{i(t-k)}+\varepsilon$

Where, $t=1,2,3 \ldots \ldots, T ; i=1,2,3 \ldots \ldots ., N ; \Phi_{i k}$ is a $q \times q$ matrix;

$\varepsilon_{i t}$ is the $q \times 1$ vector of disturbances; and

$b_{t}$ which is a vector of deterministic components is equal to 1 .

That is, $\delta_{i}$ is a $q \times 1$ or $q \times 2$ matrix of parameters.

Therefore, $\delta_{i} b_{t}$ is a $q \times 1$ vector with the k-th element which is equal to $\delta_{1 i k}$ or $\delta_{1 i k}+\delta_{2 i k}+\ldots . . t$ denoting the model's deterministic component. 
Explicitly,

$\Delta Y_{i t}=\delta_{i} b_{t}+\Pi_{i} Y_{i(t-1)}+\sum_{k=1}^{m-1} \Gamma_{i k} \Delta Y_{i(t-k)}+\varepsilon_{i t}$

Where, $t=1,2,3 \ldots . t ; i=1,2,3 \ldots \ldots . . . N$;

$\Gamma_{i k}=-\sum_{w=k+1}^{m} \Phi_{i w}$ for $k=1,2,3, \ldots \ldots,(m-1)$ and,

$\Pi_{i}=-\left(\mathrm{I}_{j}-\sum_{k=1}^{m} \Phi_{i k}\right)$. Moreover, $\Gamma_{i}=\left(\Gamma_{1 i}, \Gamma_{2 i}, \Gamma_{3 i}, \ldots \ldots . . \Gamma_{i(m-1)}\right)$

and $\left.X_{i t}=\left(\Delta Y_{i(t-1)^{\prime}}, \Delta Y_{i(t-2)}, \Delta Y_{i(t-3)}, \ldots \ldots \ldots \ldots . . . \Delta Y_{i, t-(m-1)}\right)^{\prime}\right)^{\prime}$.

Equation 3.5 can be re-written as:

$\Delta Y_{i t}=\delta_{i} b_{t}+\Pi_{i} Y_{i(t-1)}+\Gamma_{i} X_{i t}+\varepsilon_{i t}$

For a given time-period $t$, model 3.6 can be stacked over the cross-section $i$ to obtain;

$\Delta Y_{t}=\delta b_{t}+\Pi Y_{t-1}+\Gamma X_{t}+\varepsilon_{t}$

For every $t$ ranges from 1,2,3,

,$T$.

In the same manner, equation 3.7 can be expressed in a matrix form as:

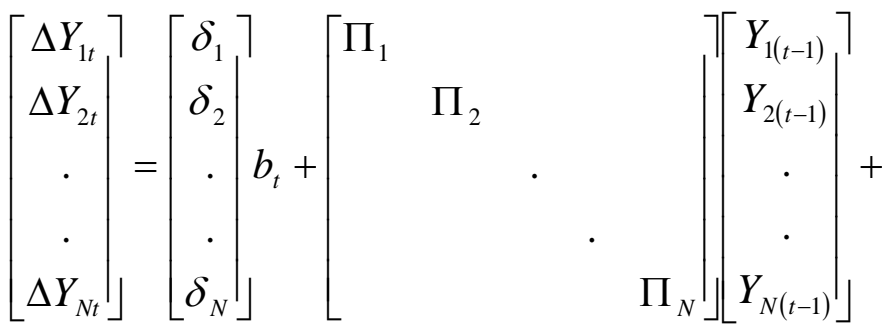

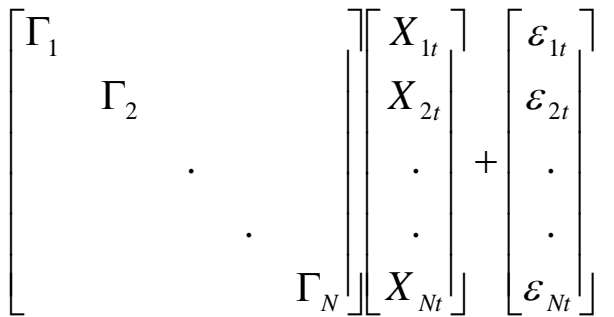

Equation 3.6 is the usual VEC model.

Thus, it is assumed that $\varepsilon_{i t}$ is I.I.D with a mean value equal to zero and co variance matrix denoted as: 


$$
\begin{aligned}
& \Omega=\left[\begin{array}{cccc}
\Omega_{11} & \cdot & \cdot & \Omega_{1 N} \\
\cdot & \cdot & \\
\cdot & & \cdot & \\
\Omega_{N 1} & \cdot & \cdot & \Omega_{N N}
\end{array}\right] . \text { This is } N q \times N q \text { positive definite matrix such that } \\
& \Omega_{i k} \equiv \operatorname{var}\left(\varepsilon_{i t}\right) .
\end{aligned}
$$

Following the study of Groen and Kleibergen (2003),

If $\Pi_{i}$ is decomposed into $\alpha_{i} \beta_{i}^{\prime}$ where, $\alpha_{i}$ and $\beta_{i}$ are of dimension $q \times r_{i}$ with $r_{i}$ equal to rank $\left(\Pi_{i}\right)<q$.

This denotes that the cointegration rank varies across cross-sections which is in tandem with the existing literature on panel cointegration that posits that individual cross-sections usually have the same cointegration rank, that is $r_{i}=r$ for all $i$.

When $\Pi=\alpha \beta^{\prime}$, then the long run coefficient matrix $\Pi$ is;

$\alpha=\left[\begin{array}{lllll}\alpha_{1} & & & & \\ & \alpha_{2} & & & \\ & & \cdot & & \\ & & & \cdot & \\ & & & & \alpha_{N}\end{array}\right]^{\prime}, \beta=\left[\begin{array}{llll}\beta_{1} & & & \\ & \beta_{2} & & \\ & & \cdot & \\ & & & \cdot \\ & & & \beta_{N}\end{array}\right]$.

Conclusively, a panel-VEC model is written as

$\Delta Y_{i t}=\delta b_{i t}+\alpha \beta^{\prime} Y_{i(t-1)}+\Gamma X_{i t}+\varepsilon_{i t}$

From equation 3.8, the short run matrix, $\Gamma$; adjustment matrix, $\alpha$ and the cointegration matrix, $\beta$ are expressed below respectively.

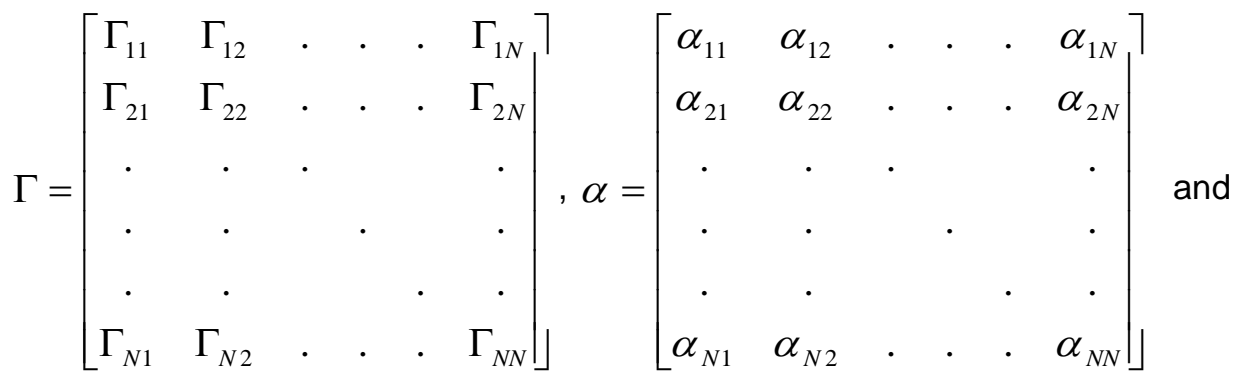




$$
\beta=\left[\begin{array}{cccccc}
\beta_{11} & \beta_{12} & \cdot & \cdot & \cdot & \beta_{1 N} \\
\beta_{21} & \beta_{22} & \cdot & \cdot & \cdot & \beta_{2 N} \\
\cdot & \cdot & \cdot & & & \cdot \\
\cdot & \cdot & & \cdot & & \cdot \\
\cdot & \cdot & & \cdot & \cdot \\
\beta_{N 1} & \beta_{N 2} & \cdot & \cdot & \cdot & \beta_{N N}
\end{array}\right] .
$$

The unrestricted matrices of $\alpha$ and $\beta$ are of the dimension $N q \times r$, where, $r \equiv r_{1}+r_{2}+\ldots . .+r_{N}<N q$.

Therefore, following Odhiambo (2014), the ECM- based Granger causality model is written as;

$$
\begin{aligned}
& {\left[\begin{array}{c}
\Delta R O A_{i t} \\
\Delta D P O R_{i t} \\
\Delta R E R A_{i t} \\
\Delta C A R_{i t}
\end{array}\right]=\left[\begin{array}{l}
\theta_{0} \\
\beta_{0} \\
\alpha_{0} \\
\delta_{0}
\end{array}\right]+\sum_{k=1}^{p}\left[\begin{array}{cccc}
\theta_{1 i} & \theta_{2 i} & \theta_{3 i} & \theta_{4 i} \\
\beta_{1 i} & \beta_{2 i} & \beta_{3 i} & \beta_{4 i} \\
\alpha_{1 i} & \alpha_{2 i} & \alpha_{3 i} & \alpha_{4 i} \\
\delta_{1 i} & \delta_{2 i} & \delta_{3 i} & \delta_{4 i}
\end{array}\right]\left[\begin{array}{c}
\Delta R O A_{i(t-k)} \\
\Delta D P O R_{i(t-k)} \\
\Delta R E R A_{i(t-k)} \\
\Delta C A R_{i(t-k)}
\end{array}\right]+} \\
& {\left[\begin{array}{c}
\theta_{5} \\
\beta_{5} \\
\alpha_{5} \\
\delta_{5}
\end{array}\right] E T_{t-1}+\left[\begin{array}{l}
u_{1 i t} \\
u_{2 i t} \\
u_{3 i t} \\
u_{4 i t}
\end{array}\right]} \\
& \Delta R O A_{i t}=\theta_{0}+\sum_{k=1}^{p} \theta_{1 i} \Delta R O A_{i(t-k)}+\sum_{k=1}^{p} \theta_{2 i} \Delta D P O R_{i(t-k)}+\sum_{k=1}^{p} \theta_{3 i} \Delta R E R A_{i(t-k)}+ \\
& \sum_{k=1}^{p} \theta_{4 i} \Delta C A R_{i(t-k)}+\theta_{5} E C T_{t-1}+u_{1 i t} \\
& \Delta D P O R_{i t}=\beta_{0}+\sum_{k=1}^{p} \beta_{1 i} R O A_{(t-k)}+\sum_{k=1}^{p} \beta_{2 i} \Delta D P O R_{i(t-k)}+\sum_{k=1}^{p} \beta_{3 i} \Delta R E R A_{i(t-k)}+ \\
& \sum_{k=1}^{p} \beta_{4 i} \Delta C A R_{i(t-k)}+\beta_{5} E C T_{t-1}+u_{2 i t} \\
& \Delta R E R A_{i t}=\alpha_{0}+\sum_{k=1}^{p} \alpha_{1 i} \Delta R O A_{i(t-k)}+\sum_{k=1}^{p} \alpha_{2 i} \Delta D P O R_{i(t-k)}+\sum_{k=1}^{p} \alpha_{3 i} \Delta R E R A_{i(t-k)}+ \\
& \sum_{k=1}^{p} \alpha_{4 i} \Delta C A R_{i(t-k)}+\alpha_{5} E C T_{t-1}+u_{3 i t}
\end{aligned}
$$




$$
\begin{gathered}
\Delta C A R_{i t}=\delta_{0}+\sum_{k=1}^{p} \delta_{1 i} \Delta R O A_{i(t-k)}+\sum_{k=1}^{p} \delta_{2 i} \Delta D P O R_{i(t-k)}+\sum_{k=1}^{p} \delta_{3 i} \Delta R E R A_{i(t-k)}+ \\
\left.\sum_{k=1}^{p} \delta_{4 i} \Delta C A R_{i(t-k)}+\delta_{5} E C T_{t-1}+u_{4 i t} \ldots \ldots \ldots \ldots \ldots \ldots \ldots \ldots \ldots \ldots \ldots \ldots \ldots \ldots \ldots \ldots \ldots \ldots \ldots \ldots \ldots \ldots \ldots \ldots \ldots \ldots \ldots \ldots \ldots . .12\right) \\
\theta_{0}, \beta_{0}, \alpha_{0}, \delta_{0} \text { are respective constants. } \theta_{1}-\theta_{5}, \beta_{1}-\beta_{5}, \alpha_{1}-\alpha_{5}, \delta_{1}-\delta_{5}
\end{gathered}
$$

are respective estimated coefficients. $\Delta$ denotes the first difference operator. $E C T_{t-1}$ represents the one-year lagged error correction term. It is the cointegrating vector that acts as the speed of adjustment for the long-run association among the variables. $u_{1 i t}-u_{4 i t}$ are mutually uncorrelated stochastic (white noise) error terms with finite covariance matrix and zero mean value.

$t$ is the time period that ranges from $1,2, \ldots \ldots .10, i$ is the cross-section (banks) that ranges from $1,2, \ldots \ldots . .250$ and lastly, $\mathrm{k}$ is the number of lags while $p$ is the optimal lag length selected by using the sequential modified LR test statistic, final prediction error (FPE), Akaike information criterion (AIC), Schwarz Bayesian criterion (SBC) and Hannan-Quinn information criterion.

To conduct a multivariate test, $C A R_{i t}$, which is the measure of the capital adequacy ratio was included to avoid the omission of germane variables that can cause simultaneity bias and thereby lead to a bogus relationship between the variables (Gujarati \& Porter, 2003). For any commercial bank to adopt a policy it must be adequately capitalised to justify continuity of banking activities and hence, persistent future growth, since banks address risk by maintaining a high degree of capitalisation.

A priori Expectation: It is expected from this study that $\beta_{1}-\beta_{3}>0$ (Agyei \& Marfo-Yiadom, 2011; Hamid et al., 2016; Ibrahim, 2016). There should be either a uni-directional or bi-directional causal relationship between dividend policy and banks' return.

\section{Estimation of Model}

\subsection{Preliminary Analysis}

Panel Unit Root: Secondary data is used in this study; however, before analysing this secondary data, a stationary test has to be conducted on the data so as to detect the order of integration in case there is a cointegrating relationship between the variables and to id a spurious analysis. Empirical findings have affirmed that none of the various unit root tests is free from power properties and size shortcomings; hence, to ensure authentic evidence as to the order of integration, several panel unit root tests were conducted.

Generally, the structure of panel unit root testing is as follows:

$$
\Delta m_{i t}=\rho_{i} m_{i(t-1)}+\sum_{j=1}^{p_{j}} \phi_{i} \Delta m_{i(t-j)}+\alpha_{i} n_{i t}+\varepsilon_{i t}
$$


Where, $n_{i t}=$ deterministic components. While the null hypothesis $\left(\rho_{i}=0\right)$ signifies that $m$ process has a unit root for each cross-section $i$, the alternative hypothesis $\rho_{i}<0$ means the process is stationary around the deterministic fraction.

Table 1. Levin Lin and Chu (LLC), Augmented Dickey Fuller (ADF) and Maddala and Wu (PP) Fisher-type unit root tests

\begin{tabular}{|c|c|c|c|c|c|l|}
\hline \multirow{2}{*}{ Variable } & \multicolumn{3}{|c|}{ Levin, Lin, Chu (None) } & \multicolumn{2}{c|}{ Levin, Lin, Chu (Individual intercept) } \\
\cline { 2 - 7 } & Order & $\mathbf{t}^{\star}$ Stat & Prob- Value & Order & $\mathbf{t}^{\star}$ Stat & Prob- Value \\
\hline ROA & $\mathrm{I}(1)$ & -48.6650 & $0.0000^{\star \star \star}$ & $\mathrm{I}(1)$ & -36.6509 & $0.0000^{\star \star \star}$ \\
\hline DPOR & $\mathrm{I}(1)$ & -45.7437 & $0.0000^{\star \star \star}$ & $\mathrm{I}(1)$ & 48.8162 & $0.0000^{\star \star \star}$ \\
\hline RERA & $\mathrm{I}(1)$ & -49.6430 & $0.0000^{\star \star \star}$ & $\mathrm{I}(1)$ & 322.727 & $0.0000^{\star \star \star}$ \\
\hline CAR & $\mathrm{I}(1)$ & -56.0963 & $0.0000^{\star \star \star}$ & $\mathrm{I}(1)$ & -46.3578 & $0.0000^{\star \star \star}$ \\
\hline
\end{tabular}

Source: Authors' estimation, 2018. Note that “***” represents $1 \%$ level of significance

\begin{tabular}{|c|c|c|c|c|c|c|}
\hline Variables & \multicolumn{3}{|c|}{$\begin{array}{c}\text { ADF Fisher Chi-square Unit-root test } \\
\text { (None) }\end{array}$} & \multicolumn{3}{|c|}{$\begin{array}{c}\text { ADF Fisher Chi-square Unit-root test } \\
\text { (Individual intercept) }\end{array}$} \\
\cline { 2 - 7 } & Order & $\mathbf{t}^{\star}$ Stat & Prob- Value & Order & $\mathbf{t}^{\star}$ Stat & Prob- Value \\
\hline ROA & $\mathrm{I}(1)$ & 1960.44 & $0.0000^{\star \star \star}$ & $\mathrm{I}(1)$ & 1061.55 & $0.0000^{\star \star \star}$ \\
\hline DPOR & $\mathrm{I}(1)$ & 2118.55 & $0.0000^{\star \star \star}$ & $\mathrm{I}(1)$ & 1152.86 & $0.0000^{\star \star \star}$ \\
\hline RERA & $\mathrm{I}(1)$ & 2138.62 & $0.0000^{\star \star \star}$ & $\mathrm{I}(1)$ & 1147.86 & $0.0000^{\star \star \star}$ \\
\hline CAR & $\mathrm{I}(1)$ & 1944.10 & $0.0000^{\star \star \star}$ & $\mathrm{I}(1)$ & 1122.12 & $0.0000^{\star \star \star}$ \\
\hline
\end{tabular}

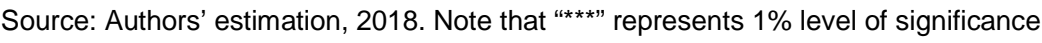

\begin{tabular}{|c|c|c|c|c|c|c|}
\hline Variables & \multicolumn{3}{|c|}{$\begin{array}{c}\text { PP Fisher-type Chi Square Unit root-test } \\
\text { (None) }\end{array}$} & $\begin{array}{r}\text { PP Fisher-type Chi Square Unit root-test } \\
\text { (Individual intercept) }\end{array}$ \\
\cline { 2 - 7 } & Order & $\mathbf{t}^{\star}$ Stat & Prob- Value & Order & $\mathbf{t}^{\star}$ Stat & Prob- Value \\
\hline ROA & $\mathrm{I}(1)$ & 3188.80 & $0.0000^{\star \star \star}$ & $\mathrm{I}(1)$ & 2352.11 & $0.0000^{\star \star \star}$ \\
\hline DPOR & $\mathrm{I}(1)$ & 3345.97 & $0.0000^{\star \star \star}$ & $\mathrm{I}(1)$ & 2410.29 & $0.0000^{\star \star \star}$ \\
\hline RERA & $\mathrm{I}(1)$ & 3434.75 & $0.0000^{\star \star \star}$ & $\mathrm{I}(1)$ & 2447.75 & $0.0000^{\star \star \star}$ \\
\hline CAR & $\mathrm{I}(1)$ & 3398.07 & $0.0000^{\star \star \star}$ & $\mathrm{I}(1)$ & 2702.61 & $0.0000^{\star \star \star}$ \\
\hline
\end{tabular}

Source: Authors' estimation, 2018. Note that “***” represents $1 \%$ level of significance

The panel unit root test presented in the above table shows that all the variables were stationary at first differencing (order one). Return on assets, the dividend policy ratio, retention ratio and capital adequacy ratio were all stationary at order one (I (1)) at both cross-section and individual level during the period under investigation. The reason is that the probability of Levin, Lin and Chin t statistic 
values: $0.000,0.000,0.000$ and 0.000 ; the Augmented Dickey Fuller (ADF) test statistic and Philip Perron statistic values: $0.000,0.000,0.000$ and 0.000 for each of the variables was less than the probability of the error margin 0.05 allowed for the estimate in this study. This implies that there is a short run equilibrium relationship between the variables under investigation. The short run stability of these variables revealed by the panel unit root test led to further description of the variables, the level of correlation between them and the estimation of cointegration to determine the long run equilibrium relationship or stability of the linear combination of the variables in the long run.

Vector Auto-Regression (VAR) Optimal Lag Selection: To be able to determine the optimal lag for the purpose of this study, different criteria are used to choose the optimal lag structure for the model. According to Hyndman and Athanasopoulos (2014), AIC criteria tend to choose larger number of lags, hence, for VAR and VEC analysis, SIC is preferable.

Table 2. Optimal Lag Selection of Series: ROA, DPOR, RERA, CAR

\begin{tabular}{|c|c|c|c|c|c|c|}
\hline LAG & LOGL & LR & FPE & AIC & SIC & HQIC \\
\hline 0 & 1059.431 & NA & $1.46 e-07$ & -4.388485 & -4.353759 & -4.374836 \\
\hline 1 & 1704.240 & 1276.214 & $1.07 e-08$ & -7.003078 & -6.829446 & -6.934833 \\
\hline 2 & 1777.123 & 143.0380 & $8.43 e-09$ & -7.239597 & $-6.927058^{\star}$ & $-7.11675^{\star}$ \\
\hline 3 & 1787.682 & 20.54757 & $8.63 e-09$ & -7.216974 & -6.765529 & -7.039536 \\
\hline 4 & 1815.669 & 53.99549 & $8.21 e-09$ & -7.266815 & -6.676464 & -7.034782 \\
\hline 5 & 1836.931 & $40.66732^{\star}$ & $8.03 e-09^{\star}$ & $-7.288695^{\star}$ & -6.559437 & -7.002065 \\
\hline 6 & 1846.703 & 18.52819 & $8.24 e-09$ & -7.262799 & -6.394635 & -6.921572 \\
\hline 7 & 1857.278 & 19.87432 & $8.43 e-09$ & -7.240240 & -6.233170 & -6.844418 \\
\hline 8 & 1866.838 & 17.80843 & $8.66 e-09$ & -7.213463 & -6.067487 & -6.763044 \\
\hline
\end{tabular}

Source: Authors' estimation, 2018. Note that $\left(^{*}\right)$ indicates lag order selected by each criterion; LR: Sequential modified LR test statistic (each at 5 Percent level of significance); FPE: final prediction error; AIC: Akaike Information Criterion; SIC: Schwarz information criterion; HQIC: Hannan-Quinn information criterion.

Table 2 shows the result of the vector error correction model of lag length to be selected for this study. A vector error correction model of lag order of four (5) is found using AIC with a value of -7.2887 while a vector error correction model of lag order of two (2) is revealed using SIC and HQIC with values given as -6.9271 and -7.1168 , respectively. All these information criteria are statistically significant at 5 percent level. Based on this evidence, a vector error correction model of lag order two (2) which is the smallest lag order as revealed by SIC and HQIC is selected for this study.

Panel Cointegration Test: According to Uddin, Shahbaz, Arouri, and Teulon (2014), a cointegration test is conducted to test for the significant deviation of integrated variables from a certain relationship. Cointegration means the presence of a long-run association between economic variables such that co-integrated variables give room for the correction of short-term disturbances in the long-term. From the evidence of the unit root test that the variables are integrated at the same order I (1), there is the need to test for the existence of a long-run association between the variables. 
In this study, Kao ADF residual based and Johansen Fisher panel cointegration tests were considered.

Table 3. Kao ADF Residual based Co-integration Test of Series:

ROA DPOR RERA CAR

\begin{tabular}{|l|l|l|}
\hline \multicolumn{2}{|l|}{ Ho: There is no Co-integration $\left(H_{0}: \omega=1\right)$} \\
\hline \multicolumn{3}{|c|}{ Trend Assumption: No deterministic Trend } \\
\hline & t-Statistic & Prob \\
\hline ADF & -14.6826 & $0.000^{\star \star \star}$ \\
\hline
\end{tabular}

Source: Author's estimation, 2018. Note that “***” represents rejection of null hypothesis at $5 \%$ level of significance.

Estimate from the Kao Residual ADF test in Table 3 was significant at 5 Percent with t-statistics -14.6826 , hence, the null hypothesis is rejected and there is confirmed evidence that the variables are co-integrated in the long run.

Table 4. Johansen Fisher-Based Cointegration Test of Series: ROA, DPOR, RERA CAR

\begin{tabular}{|c|c|c|c|c|}
\hline \multicolumn{5}{|c|}{ Ho: There is no Co-integration } \\
\hline \multicolumn{5}{|c|}{ Co-integration Rank Test using Trace Statistic } \\
\hline Eigen value & Trace Statistic & $5 \%$ Critical Value & Prob & Hypothesised No. of CE(s) \\
\hline 0.155713 & 727.6523 & 47.85613 & 0.0001 & None $* * \star$ \\
\hline 0.101574 & 437.5352 & 29.79707 & 0.0001 & At most 1 *** \\
\hline 0.075369 & 253.9477 & 15.49471 & 0.0001 & At most $2 * \star *$ \\
\hline 0.067420 & 119.6382 & 3.841466 & 0.0000 & At most $3 * \star \star$ \\
\hline \multicolumn{5}{|c|}{ Co-integration Rank Test using Maximum Eigen Value Statistic } \\
\hline Eigen value & $\begin{array}{l}\text { Maximum Eigen } \\
\text { Value Statistic }\end{array}$ & $5 \%$ Critical Value & Prob & Hypothesised No. of CE(s) \\
\hline 0.155713 & 290.1171 & 27.58434 & 0.0001 & None $* \star \star$ \\
\hline 0.101574 & 183.5875 & 21.13162 & 0.0001 & At most $1^{\star \star \star}$ \\
\hline 0.075369 & 134.3095 & 14.26460 & 0.0001 & At most $2 * \star \star$ \\
\hline 0.067420 & 119.6382 & 3.841466 & 0.0000 & At most $3 * \star \star$ \\
\hline
\end{tabular}

Source: Authors' estimation, 2018. Note that “***” represents rejection of null hypothesis at $5 \%$ level of significance.

In the Johansen Panel cointegration test, much emphasis is laid on the number of lags. Hence, optimal lag two (2) was used for all the estimations in this study including this test based on the Schwarz Information Criterion (SIC). Using the Johansen Fisher based cointegration test methodology to estimate the co-integrating 
rank test; two likelihood estimators were used for the co-integrating rank: a trace test and a maximum Eigen value test. The co-integrating rank was formally tested using the trace and the maximum Eigen value statistic. These test statistics indicates four co-integrating vectors at 5 percent level of significance as presented in Table 4 above. This finding implies that a long-run equilibrium relationship exists between the variables under study.

Thus, the stability of the dividend policy captured by the dividend payout ratio, retention ratio and capital adequacy ratio will affect banking performance measured by return on assets in both the short and long run. From the above tables, the Maximum-Eigen value test indicates three normalized co-integrating equation(s) at 5 percent significance level. The details of the three normalized co-integrating equations and their adjustment coefficients are presented in Table 5 below.

Table 5. Cointegration Equations

\begin{tabular}{|c|c|c|c|}
\hline ROA & RERA & CAR & \multicolumn{1}{c|}{ DPOR } \\
\hline 1.000000 & 0.000000 & 0.000000 & $0.00838(0.00263)$ \\
\hline 0.000000 & 1.000000 & 0.000000 & $0.16749(0.01547)$ \\
\hline 0.000000 & 0.000000 & 1.000000 & $0.09121(0.01756)$ \\
\hline Adjustment coefficients (standard error in parentheses) \\
\hline$D($ ROA $)$ & $-0.38154(0.02582)$ & $-0.00231(0.00525)$ & $-0.00874(0.00556)$ \\
\hline$D($ RERA $)$ & $0.09651(0.19330)$ & $-0.48807(0.03932)$ & $0.02949(0.04164)$ \\
\hline$D($ CAR $)$ & $0.46804(0.07489)$ & $-0.03104(0.01523)$ & $-0.19450(0.01613)$ \\
\hline$D($ DPOR $)$ & $-0.65272(0.62101)$ & $0.71888(0.12632)$ & $-0.34629(0.13379)$ \\
\hline
\end{tabular}

Source: Authors' estimation, 2018
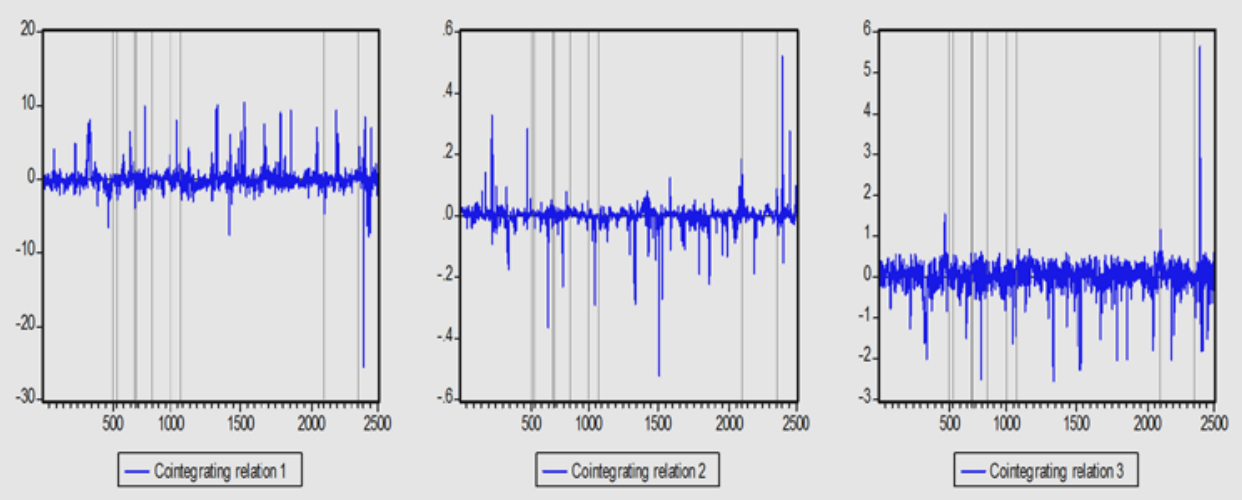

Fig. 1. Graphical Representation of Co-integrating Equations

Source: Authors' estimation, 2018 
Table 5 and Figure 1 present the normalized co-integrating equation(s) coefficients with their standard error in parentheses. The normalized co-integrating coefficients only load on the DPOR with positive coefficients. Thus, the coefficients of DPOR 0.0084 , 0.1675 and 0.0912 which are statistically significant based on the standard error test reveal that banking performance as shown by the co-integrating equations can be determined by future-state and the stability of ROA, the retention ratio and capital adequacy while the dividend payout ratio mainly determines the current level of banking performance to move in the right direction to bring the system back to equilibrium. The cointegration adjusted coefficients measure the long-run equilibrium or the stability of banking performance.

The ROA value of -0.382 in the first co-integrating equation reveals a discouraging level of performance and calls for improvement. The DPOR of -0.653 reveals the negative impact of dividend payout policy on the banking performance in SSA. This is similar to the findings of M'rabet and Bouijat (2016) and Farsio et al. (2004); however, the RERA and CAR values of 0.097 and 0.468 , respectively contribute positively to ROA in SSA (Omran \& Pointon, 2004). In the second and third co-integrating equation, the banking industry's performance improved as, while still negative, the performance level stood at -0.002 and -0.009 , respectively. This result was enhanced by improvement in DPOR which contributes positively and significantly at 0.719 to ROA despite the negative impact of RERA and CAR. It implies that the more attention that is paid to satisfying shareholders through dividend payments, the better the performance of the banking industry in the long run.

\subsection{Vector Error Correction Estimations}

According to Mahadevan and Asafu-Adjaye (2007), the two common methods of detecting the direction of causality between co-integrated variables are VAR and VECM. VECM is used in this study to show both long and short run causality between the variables based on affirmation of the long run association between the variables. The VECM with four (4) simultaneous equations is estimated to examine the short run properties of the long run relationships between the series. A VECM is a restricted VAR that is used for non-stationary co-integrated series. VEC is of more merit than VAR because its cointegration relations are built into its specification such that the endogenous variables' long-run behaviour is restricted to cause convergence in the co-integrating relationships, enabling short-run adjustment dynamics in the series. The cointegration term built into the VECM is called the error correction term (ECT) since any deviation from the long-run equilibrium is expected to be corrected with a gradual speed of short-run adjustment. Following Asari et al. (2011) and Hyndman and Athanasopoulos (2014) studies, SIC is also used as a criterion to choose optimal lag two (2) used in this study as AIC tends to choose a larger number of lags that can render the VEC estimate insignificant.

Table 6. Vector Error Correction Estimates

\begin{tabular}{|c|c|c|c|c|}
\hline Co-integrating Eq: & CointEq1 & CointEq2 & CointEq3 & \\
\hline ROA(-1) & 1.000000 & 0.000000 & 0.000000 & \\
\hline RERA(-1) & 0.000000 & 1.000000 & 0.000000 & \\
\hline CAR(-1) & 0.000000 & 0.000000 & 1.000000 & \\
\hline & 0.00838 & 0.16749 & 0.09121 & \\
DPOR(-1) & $(0.0026)$ & $(0.0155)$ & $(0.0176)$ & \\
\hline
\end{tabular}




\begin{tabular}{|c|c|c|c|c|}
\hline Co-integrating Eq: & CointEq1 & CointEq2 & CointEq3 & \\
\hline C1 & -0.013610 & -0.382556 & -0.049722 & \\
\hline Error Correction: & $\triangle R O A$ & $\triangle R E R A$ & $\triangle C A R$ & $\triangle D P O R$ \\
\hline CointEq1 & $\begin{array}{l}-0.38154 \\
(0.0258)\end{array}$ & $\begin{array}{l}0.09651 \\
(0.1934)\end{array}$ & $\begin{array}{l}0.46804 \\
(0.0749)\end{array}$ & $-0.65272(0.6214)$ \\
\hline CointEq2 & $\begin{array}{c}-0.00231 \\
(0.0053) \\
\end{array}$ & $\begin{array}{r}-0.48807 \\
(0.0393) \\
\end{array}$ & $\begin{array}{c}-0.03104 \\
(0.0152) \\
\end{array}$ & $\begin{array}{l}0.71888 \\
(0.1264)\end{array}$ \\
\hline CointEq3 & $\begin{array}{l}-0.00874 \\
(0.0056) \\
\end{array}$ & $\begin{array}{l}0.02949 \\
(0.0417) \\
\end{array}$ & $\begin{array}{l}-0.19450 \\
(0.0161) \\
\end{array}$ & $-0.34629(0.1339)$ \\
\hline$\Delta R O A_{(-1)}$ & $\begin{array}{c}-0.22603 \\
(0.0269)\end{array}$ & $\begin{array}{l}-0.09999 \\
(0.2012)\end{array}$ & $\begin{array}{l}-0.30195 \\
(0.0780)\end{array}$ & $\begin{array}{l}0.39566 \\
(0.6465)\end{array}$ \\
\hline$\Delta R O A_{(-2)}$ & $\begin{array}{c}-0.09791 \\
(0.0221) \\
\end{array}$ & $\begin{array}{c}-0.00711 \\
(0.1656) \\
\end{array}$ & $\begin{array}{c}-0.10629 \\
(0.0642) \\
\end{array}$ & $\begin{array}{l}0.19842 \\
(0.5320)\end{array}$ \\
\hline$\Delta R E R A_{(-1)}$ & $\begin{array}{l}0.00456 \\
(0.0060)\end{array}$ & $\begin{array}{l}-0.19517 \\
(0.0451)\end{array}$ & $\begin{array}{l}0.01171 \\
(0.0175)\end{array}$ & $-0.40673(0.1448)$ \\
\hline$\Delta R E R A_{(-2)}$ & $\begin{array}{l}0.00433 \\
(0.0048) \\
\end{array}$ & $\begin{array}{r}-0.02681 \\
(0.0362) \\
\end{array}$ & $\begin{array}{l}0.00654 \\
(0.0140)\end{array}$ & $-0.14503(0.1162)$ \\
\hline$\Delta C A R_{(-1)}$ & $\begin{array}{l}-0.00137 \\
(0.0073)\end{array}$ & $\begin{array}{l}-0.07773 \\
(0.0546)\end{array}$ & $\begin{array}{l}-0.15587 \\
(0.0212)\end{array}$ & $\begin{array}{l}0.35449 \\
(0.1754)\end{array}$ \\
\hline$\Delta C A R_{(-2)}$ & $\begin{array}{l}0.00903 \\
(0.0064) \\
\end{array}$ & $\begin{array}{l}0.01448 \\
(0.0481) \\
\end{array}$ & $\begin{array}{c}-0.03648 \\
(0.0186) \\
\end{array}$ & $\begin{array}{l}0.09437 \\
(0.1544)\end{array}$ \\
\hline$\triangle D P O R_{(-1)}$ & $\begin{array}{l}0.00265 \\
(0.0018) \\
\end{array}$ & $\begin{array}{l}0.03276 \\
(0.0134) \\
\end{array}$ & $\begin{array}{l}0.00957 \\
(0.0052)\end{array}$ & $-0.45489(0.0430)$ \\
\hline$\triangle D P O R_{(-2)}$ & $\begin{array}{l}0.00206 \\
(0.0015)\end{array}$ & $\begin{array}{l}0.02593 \\
(0.0115)\end{array}$ & $\begin{array}{l}0.00743 \\
(0.0045) \\
\end{array}$ & $-0.16638(0.0369)$ \\
\hline $\mathrm{C} 2$ & $\begin{array}{r}-0.00047 \\
(0.0006) \\
\end{array}$ & $\begin{array}{l}-0.00293 \\
(0.0047) \\
\end{array}$ & $\begin{array}{l}0.00136 \\
(0.0018) \\
\end{array}$ & $\begin{array}{l}0.00622 \\
(0.0150)\end{array}$ \\
\hline R-squared & 0.308348 & 0.270238 & 0.146439 & 0.179245 \\
\hline Adj. R-squared & 0.303878 & 0.265522 & 0.140923 & 0.173940 \\
\hline Sum sq. Resids & 1.138343 & 63.79993 & 9.576733 & 658.5193 \\
\hline S.E. equation & 0.025862 & 0.193611 & 0.075012 & 0.622020 \\
\hline F-statistic & 68.97955 & 57.29713 & 26.54541 & 33.79087 \\
\hline Log likelihood & 3838.618 & 388.1833 & 2013.411 & -1612.262 \\
\hline Akaike AIC & -4.465132 & -0.438954 & -2.335369 & 1.895288 \\
\hline Schwarz SC & -4.427000 & -0.400821 & -2.297237 & 1.933421 \\
\hline Mean dependent & -0.000533 & -0.003395 & 0.000984 & 0.006297 \\
\hline S.D. dependent & 0.030997 & 0.225913 & 0.080931 & 0.684382 \\
\hline
\end{tabular}

Source: Author's estimation, 2018. Note that standard errors (S.E) are in parenthesis

The presence of cointegration between variables suggests a long-term relationship between the variables under consideration. The VECM can then be applied. The vector error correction estimate with the standard error in parenthesis for the long run relationship between dividend policy and banking performance for three cointegrating equations is presented in Table 6 above. To establish a long-run relationship, the ECT, that is, the coefficients of $\theta_{5}, \beta_{5}, \alpha_{5}$ and $\delta_{5}$ should be negative and statistically significant. A negative and significant ECT coefficient indicates that any short-term fluctuations between the regressors and the dependent variable will result in a stable long run relationship between the variables. The ECTs $\left(E C T_{t-1}\right)$ are correctly signed and significant for the three (3) co-integrating 
equations except RERA and CAR in COINTEQ1, DPOR in COINTEQ2 and RERA in COINTEQ3. This signals further that there is a possibility of causation between the variables in the models whose error terms are correctly signed. Furthermore, the $\mathrm{C} 1$ in the co-integrating equation is also correctly signed and it reveals that it will take $0.014,0.383$ and 0.050 percent, respectively for the maladjustment in the cointegrating equations 1,2 and 3 to adjust to the long run equilibrium or stability. In examining the impact of the error correction of the dividend policy on banking performance, it was found from the fitted vector error correction mechanism that $\mathrm{ROA}$ at lag one and two and capital adequacy at lag one, have an inverse relationship with banking performance. Thus, $\operatorname{ROA}_{(-1)}, \operatorname{ROA}_{(-2)}$ and $\operatorname{CAR}_{(-1)}$ will worsen ROA by $22.65,9.79$ and 0.14 percent, respectively.

However, RERA $(-1)$ and $\operatorname{RERA}_{(-2)}, \operatorname{CAR}(-2)$ and $\operatorname{DPOR}_{(-1)}$ and $\operatorname{DPOR}_{(-2)}$ have a direct relationship with ROA. This finding is in tandem with the empirical finding of Omran and Pointon (2004); Uwuigbe, Jafaru, and Ajayi (2012); Zhou and Ruland (2006); Ajanthan (2013); Ehikioya (2015) and Agyei and Marfo-Yiadom (2011) who concluded that dividend policy, be it payout or retention, has a positive relationship with and can affect value and shareholders' wealth across sectors and economies. However, our finding negates Onanjiri and Korankye (2014a) and Farsio et al. (2004) work that found that dividend policy has no moderating effect or relationship on/with performance. The results further reveal that $\operatorname{RERA}_{(-1)}, \operatorname{RERA}_{(-2)}, \mathrm{CAR}_{(-2)}, \mathrm{DPOR}_{(-1)}$ and $\operatorname{DPOR}_{(-2)}$ will lead to improved performance of the banking industry by $0.46,0.43,0.90,0.26$ and 0.21 percent, respectively with CAR ranking the highest. CAR serves as a cushion for banking activities; thus, a bank that meets capital requirements has the capacity to adopt policies that enhance the viability, sustainability and continuity of banking activities with few challenges. Furthermore, banks that maintain a high capital ratio level have lower funding costs because they will suffer minimal prospective bankruptcy costs (Brighi \& Venturelli, 2013; Magret, 2016; Odunga, Nyangweso, Carter, \& Mwarumba, 2013).

Furthermore, the relationship between $\operatorname{RERA}_{(-1)}, \operatorname{RERA}_{(-2)}$ with DPOR is inverse/negative to the tune of 40.6 and 14.5 percent, respectively, and there is a direct/positive relationship between $\operatorname{DPOR}_{(-1)}, \mathrm{DPOR}_{(-2)}$ with RERA at 0.33 and 2.59 percent, respectively. This suggests a change in the channel of the relationship between these two dividend-polices in the SSA commercial banking sector. The C2 estimate of -0.00047 reveals the risk involved $(0.047 \%)$ in enhancing improved bank performance through dividend policy during the period under investigation in SSA even though it is so small. The significance of the VECM is examined using the Rsquare statistic and it is shown that a 30.83 percent variation in the error associated with the performance of the banking industry can be explained by the dividend policy captured by the retention ratio, dividend payout ratio and capital adequacy ratio. The F- statistic value of $68.98>\mathrm{F}_{0.05}(3,1714)=3.00$ shows that the fitted VCEM is statistically significant and hence adequate and reliable in determining the causal relationship between the dividend policy and banking performance.

\subsection{Granger Causality Estimation}

The fact that there is cointegration between two variables does not specifically show the direction of the causal relationship existing between the variables, if any. According to Fisher (1993), economic theory points to a causal relationship in at least 
one direction in any co-integrated series. Granger causality tests (the Block Exogeneity Wald test and Pairwise) are conducted to detect the existence and direction of causation between the variables. In line with E. Gul and Ekinci (2006), the causal relationship (both short and long run causality) between variables can be established using probability and chi-square statistics under the null hypothesis of no causality. Table 7 below presents the estimate of chi-square statistics and the probability values.

Table 7. VEC Block Exogeneity Wald Test

\begin{tabular}{|c|c|c|c|}
\hline \multicolumn{4}{|c|}{ Null hypothesis $H_{0}$ : There is no causality } \\
\hline \multicolumn{4}{|c|}{ Dependent variable: $\triangle R O A$} \\
\hline Excluded & Chi-sq & Df & Prob. \\
\hline$\triangle R E R A$ & 0.890986 & 2 & 0.0405 \\
\hline$\triangle C A R$ & 2.315774 & 2 & 0.3141 \\
\hline$\triangle D P O R$ & 2.688046 & 2 & 0.2608 \\
\hline All & 5.547671 & 6 & 0.4757 \\
\hline \multicolumn{4}{|c|}{ Dependent variable: $\triangle R E R A$} \\
\hline$\triangle R O A$ & 0.313638 & 2 & 0.8549 \\
\hline$\triangle C A R$ & 2.521486 & 2 & 0.2834 \\
\hline$\triangle D P O R$ & 7.453895 & 2 & $0.0241^{\star *}$ \\
\hline All & 11.31361 & 6 & $0.0792^{*}$ \\
\hline \multicolumn{4}{|c|}{ Dependent variable: $\triangle C A R$} \\
\hline$\triangle R O A$ & 15.20859 & 2 & $0.0005^{\star \star \star}$ \\
\hline$\triangle R E R A$ & 0.460199 & 2 & 0.7945 \\
\hline$\triangle D P O R$ & 4.170835 & 2 & 0.1243 \\
\hline All & 23.77259 & 6 & $0.0006^{\star \star \star}$ \\
\hline \multicolumn{4}{|c|}{ Dependent variable: $\triangle D P O R$} \\
\hline$\triangle R O A$ & 0.378027 & 2 & 0.8278 \\
\hline$\triangle R E R A$ & 8.088820 & 2 & $0.0175^{\star \star}$ \\
\hline$\triangle D P O R$ & 4.091463 & 2 & 0.1293 \\
\hline All & 13.30867 & 6 & $0.0384^{\star *}$ \\
\hline
\end{tabular}

Source: Author's estimation, 2018. Note that *** represents rejection of $\mathrm{H}_{0}$ at $1 \%$, ${ }^{*}$ represents rejection of $\mathrm{H}_{0}$ at $5 \%$ and * represents rejection of $\mathrm{H}_{0}$ at $10 \%$.

The results on vector error correction Granger causality between financial performance and the dividend policy variables under consideration show the direction of the causal relationship between each pair of the variables such as ROA, retention ratio, capital adequacy ratio and dividend payout ratio. The table shows that there is uni-directional causality between RERA and ROA in SSA. This is in tandem with the findings of Omran and Pointon (2004) but contradicts those of Mougoué and Rao (2003). DPOR also has uni-directional causality with RERA. At the long run, ROA, CAR and DPOR granger cause RERA at 10 percent level of significance. ROA also has a uni-directional causality with CAR and at the long run ROA, RERA and DPOR granger cause CAR at 5 percent. There is also uni-directional 
causality between RERA and DPOR which implies that there is bi-directional causality between the retention ratio and dividend policy ratio but at the long run, ROA, RERA and CAR granger cause DPOR at 5 percent level of significance.

The findings across different economies have switched in this study in the sense that RERA granger causes ROA as opposed to DPOR even though it is unidirectional. This implies that dividend payout policy is a luxury and a negative NPV transaction as posited by Allen and Michaely (2003); DeAngelo, DeAngelo, and Stulz (2006); David and Ginglinger (2016) and Karpavičius (2014); while RERA is regarded as a policy that enhances performance and promotes future growth that leads to value creation among SSA banks. This finding of uni-directional causality between RERA and ROA in SSA banks re-affirms the findings of Al-Twaijry and Powers (2007). These scholars averred that dividend payout policy has nothing to do with future income but is simply a signal of past performance. Damodaran (2009) maintained that valuation of banks via payout policy is vague $s$ it does not show the real value of the bank. Managers strive to satisfy their shareholders' expectations due to the uncertainty, doubt and refinancing problems that might occur if they dabble in DRIPs and stop paying dividends (Acharya, Gabarro, \& Volpin, 2012). When banks retain their profit, they have capacity to fund viable projects that yield more capital gain in the long run. The risk of uncertainty is minimal provided that the management team is monitored to undertake viable investments. According to Mizuno (2007), firms should only adopt payout policy that signals past performance to shareholders if they cannot identify and explore viable investment opportunities which will yield higher returns. It is high time that banks, especially those in SSA, realise that not all dividend paying banks are healthy and that healthy companies often cut dividend payments to shareholders and explore investment opportunities (see, http://www.flickrusertaxrebate.org.uk).

To re-confirm the causal relationship between these variables, the Pairwise Granger causality test is conducted following the empirical study of Dhamala, Rangarajan, and Ding (2008) who established a causal relationship between variables using F-statistics and their respective probability values.

Table 8. Pairwise Granger Causality Test

\begin{tabular}{|l|l|l|l|l|}
\hline Null hypothesis & F-Statistics & P-Value & Decision & Type of Causality \\
\hline $\begin{array}{l}\text { DPOR does not Granger cause } \\
\text { ROA }\end{array}$ & 1.94201 & 0.143 & Accept & No causality \\
\hline $\begin{array}{l}\text { ROA does not Granger cause } \\
\text { DPOR }\end{array}$ & 0.67541 & 0.509 & Accept & No causality \\
\hline $\begin{array}{l}\text { RERA does not Granger cause } \\
\text { ROA }\end{array}$ & 2.86302 & $0.050^{\star *}$ & Reject @5\% & RERA $\rightarrow$ ROA \\
\hline $\begin{array}{l}\text { ROA does not Granger cause } \\
\text { RERA }\end{array}$ & 1.58319 & 0.205 & Accept & No Causality \\
\hline $\begin{array}{l}\text { CAR does not Granger cause } \\
\text { ROA }\end{array}$ & 6.54151 & $0.002^{\star \star *}$ & Reject@1\% & CAR $\leftrightarrow$ ROA \\
\hline $\begin{array}{l}\text { ROA does not Granger cause } \\
\text { CAR }\end{array}$ & 35.2727 & $9 . E 16^{\star \star *}$ & Reject@1\% & ROA $\leftrightarrow$ CAR \\
\hline $\begin{array}{l}\text { RERA does not Granger cause } \\
\text { DPOR }\end{array}$ & 2.76686 & $0.063^{\star}$ & Reject@10\% & RERA $\leftrightarrow$ DPOR \\
\hline
\end{tabular}




\begin{tabular}{|l|l|l|l|l|}
\hline Null hypothesis & F-Statistics & P-Value & Decision & Type of Causality \\
\hline $\begin{array}{l}\text { DPOR does not Granger cause } \\
\text { RERA }\end{array}$ & 2.33314 & $0.097^{*}$ & Reject@10\% & DPOR $\leftrightarrow$ RERA \\
\hline $\begin{array}{l}\text { CAR does not Granger cause } \\
\text { DPOR }\end{array}$ & 0.17766 & 0.837 & Accept & No causality \\
\hline $\begin{array}{l}\text { DPOR does not Granger cause } \\
\text { CAR }\end{array}$ & 2.78934 & $0.062^{\star}$ & Reject@10\% & DPOR $\rightarrow$ CAR \\
\hline $\begin{array}{l}\text { CAR does not Granger cause } \\
\text { RERA }\end{array}$ & 0.81935 & 0.441 & Accept & No causality \\
\hline $\begin{array}{l}\text { RERA does not Granger cause } \\
\text { CAR }\end{array}$ & 2.36086 & $0.095^{\star}$ & Reject@10\% & RERA $\rightarrow$ CAR \\
\hline
\end{tabular}

Source: Authors estimation, 2018. * ${ }^{\star *},{ }^{\star \star \star}$ represent $10 \%, 5 \%$ and $1 \%$ significance level.

$\rightarrow$ denotes unidirectional causality and $\leftrightarrow$ denotes bi-directional causality.

From the pairwise test in Table 8, RERA also granger cause ROA at 5 percent level of significance and this conforms to the findings generated from the VEC block exogeneity Wald test to confirm that among SSA banks, retention policy causes performance. There is also a bi-directional relationship between CAR and ROA. While it is uni-directional under the VEC Wald test, this implies that when banks adhere to the required capital conservation and buffer ratio, they will generate higher returns and if they operate with sufficient returns, they will be sufficiently liquid to finance all their activities and satisfy the requirements of the regulatory bodies, including capital adequacy.

Like the VEC Wald test, this study finds bi-directional causality between RERA and DPOR at 10 percent level of significance, which implies that when a bank explores growth opportunities, in the long run, the value created must fully maximise owners' wealth and lead to payout. Following the life cycle theory of dividend, a mature firm will need to payout dividends as much as possible because there will be limited opportunities to invest at this stage. Conclusively, this test finds that both policies, DPOR and RERA, granger cause CAR at 10 percent level. This implies that effective, suitable and implementable dividend policy results in adherence to capital requirements in the selected SSA banks for the period examined.

\section{Conclusions}

Having established the causal relationship between dividend policy and bank performance in order to bring to light different views on the two contesting policies in the banking sector, this study's findings reveal that both policies have a positive relationship with performance, but only retention policy (RERA) granger causes performance (ROA) in SSA banks. Banks across the world have long been known for their payout policy at the expense of viable investment opportunities that would enhance their activities (Jiraporn, Kim, \& Kim, 2011). However, not all banks that are paying out are healthy.

Therefore, our findings from this study illuminates the long-existing puzzle on dividend and for the benefit of banking or other sectors of the world, the following reasons are identified as reasons for firms to cut dividend payments and start re- 
investing their earnings: a) when the business model is less effective and long term growth is unlikely due to economic changes and externalities; $b$ ) the company needs to undertake a viable project or to complete the acquisition of a rival company; c) there is high degree of competition that is slowing down the growth of the company (See, www.imfultralong.org.uk).

Vividly, the final condition is indeed the situation in the banking sector in SSA. The Lerner's index of competition for SSA commercial banks is less than 0.5 which shows that they are highly competitive and have low market power. Hence, they struggle to survive and need to promote value creation by maximising all available investment opportunities to ensure that not only profit but wealth is fully maximised.

It is intensely spelt out from our findings that any firm operating agency relationship, not only banks across various economies of the world, should adopt DRIPs which is the policy this study finds causes SSA commercial banks' financial performance. It is by doing so that they can create future value and not merely signal past earnings. This thus sheds light on the puzzle of the dividend across the world, most importantly in the region's banking sector.

Just like every research do have impediments, so also does this study. The major limitation of the study is the inability to incorporate all the commercial banks in the whole 46 SSA countries (World Bank database) due to dearth of data. The lack of sufficient data is tantamount to laxity in implementation of national standards by SSA banks such that most countries are yet to adopt the international financial reporting standards (IFRS) and deposit insurance scheme. However, these limitations do not in any way affect the influence and genuineness of the findings from this study, as strong and reliable alternatives were explored. Since this study has been able to show vividly that out of the two contesting dividend policies in banking sector, retention policy is the dividend policy that causes bank performance (ROA), further research on this context should be conducted using the economic integrations or sub-regions within SSA as the case study and also, explore another measure of performance such as return on equity (ROE) or cost-to-income-ratio, this will give a room for comparison. In conclusion, further research on this subject matter in Africa and world over could extend the scope of the study by covering more than the study period examined in this study.

\section{References}

Abdella, A. B., Manual, V. (2016) A Study on the Determinants of Dividend Policies of Commercial Banks in Saudi Arabia. Imperial Journal of Interdisciplinary Research, 2(9): 1064-1073.

Abiola, J. O. (2014) Measuring and Analyzing the Effects of Dividend Policy in Banking Profits and Growth. Journal of Policy and Development Studies, 9(1): 167-178.

Acharya, V. V., Gabarro, M., Volpin, P. F. (2012) Competition for managers, corporate governance and incentive compensation. CEPR Discussion Paper No. DP8936.

Adesina, K. (2017) Dividend policy and share price valuation in Nigerian banks. 
Agbatogun, T. O., Adewumi, A. A. (2017) The Nexus of Dividend Payout and Profitability Performance of Insurance Firms in Nigeria. https://ssrn.com/ abstract=2929492.

Agyei, S. K., Marfo-Yiadom, E. (2011) Dividend policy and bank performance in Ghana. International Journal of Economics and Finance, 3(4): 202.

Agyemang Badu, E. (2013) Determinants of Dividend Payout Policy of listed Financial Institutions in Ghana. Research Journal of Finance and Accounting, http://hdl.handle.net/123456789/88.

Ajanthan, A. (2013) The relationship between dividend payout and firm profitability: A study of listed hotels and restaurant companies in Sri Lanka. International Journal of Scientific and Research Publications, 3(6): 1-6.

Akande, J. O., Kwenda, F. (2017) Competitive Condition of Sub-Saharan Africa Commercial Banks. Studia Universitatis Babes-Bolyai Oeconomica, 62(2): 55-76.

Akinlo, A. E., Egbetunde, T. (2010) Financial development and economic growth: The experience of 10 sub-Saharan African countries revisited. The Review of Finance and Banking, 2(1): 017-028.

Al-Ajmi, J. (2010) Modelling the dividend policy of banks in Gulf Cooperation Council countries. Applied Economics Letters, 17(14): 1423-1428.

Al-Twaijry, A. A., Powers, M. R. (2007) Dividend policy and payout ratio: evidence from the Kuala Lumpur stock exchange. The Journal of Risk Finance, 8(4): 349363. doi: $10.1108 / 15265940710777306$

Allen, F., Carletti, E., Cull, R., Qian, J. Q., Senbet, L., Valenzuela, P. (2014) The African financial development and financial inclusion gaps. Journal of African economies, 23(5): 614-642.

Allen, F., Michaely, R. (2003) Payout policy. Handbook of the Economics of Finance, 1, 337-429.

Asari, F., Baharuddin, N. S., Jusoh, N., Mohamad, Z., Shamsudin, N., Jusoff, K. (2011) A vector error correction model (VECM) approach in explaining the relationship between interest rate and inflation towards exchange rate volatility in Malaysia. World Applied Sciences Journal, 12(3): 49-56.

Ashraf, B. N., Zheng, C. (2015) Shareholder protection, creditor rights and bank dividend policies. China Finance Review International, 5(2): 161-186.

Beck, T., Cull, R. (2013) Banking in Africa. World Bank Policy Research Working Paper No. 6684, 1-44.

Beck, T., Demirgüç-Kunt, A., Maksimovic, V. (2004) Bank competition and access to finance: International evidence. Journal of Money, Credit and Banking, 627-648.

Brighi, P., Venturelli, V. (2013) CEFIN Working Papers No. 43. 1-33.

Byrne, J., O'Connor, T. (2017) Creditor rights, culture and dividend payout policy. Journal of multinational financial management, 39, 60-77.

Chang, T., Lee, C.-C., Chang, C.-H. (2014) Does insurance activity promote economic growth? Further evidence based on bootstrap panel Granger causality test. The European Journal of Finance, 20(12): 1187-1210.

Crane, L. (2010) Measuring financial performance: A critical key to managing risk. AoE FIELD CROPS TEAM.[online] accessed, 14. doi: www.aec.msu.edu/agecon/ blackj/Measuring

Damodaran, A. (2009) Valuing financial service firms. Stern Business. 
Datta, D., Ganguli, S. K., Chaturvedi, M. (2014) Announcement Effect of Dividend in Presence of Dividend Tax: Possible Agency Problem and Macro Level Inefficiency? South Asian Journal of Macroeconomics and Public Finance, 3(2): 195-220.

David, T., Ginglinger, E. (2016) When cutting dividends is not bad news: The case of optional stock dividends. Journal of Corporate Finance, 40, 174-191.

DeAngelo, H., DeAngelo, L., Stulz, R. M. (2006) Dividend policy and the earned/contributed capital mix: a test of the life-cycle theory. Journal of financial Economics, 81(2): 227-254.

Dhamala, M., Rangarajan, G., Ding, M. (2008) Estimating Granger causality from Fourier and wavelet transforms of time series data. Physical review letters, 100(1): 018701-018730. doi: https://doi.org/10.1103/PhysRevLett.100.018701

Ehikioya, B. I. (2015) An Empirical Investigation of the Impact of Dividend Policy on the Performance of Firms in Developing Economies: Evidence from Listed Firms in Nigeria. International Journal of Finance and Accounting, 4(5): 245-252.

Farsio, F., Geary, A., Moser, J. (2004) The relationship between dividends and earnings. Journal for Economic Educators, 4(4): 1-5.

Fisher, A. M. (1993) Integer Cantor sets and an order-two ergodic theorem. Ergodic Theory and Dynamical Systems, 13(01): 45-64.

Flamini, V., Schumacher, M. L., McDonald, M. C. A. (2009) The determinants of commercial bank profitability in Sub-Saharan Africa: International Monetary Fund.

Goddard, J., McMillan, D. G., Wilson, J. O. (2006) Dividend smoothing vs dividend signalling: evidence from UK firms. Managerial Finance, 32(6): 493-504.

Groen, J., Kleibergen, F. (2003) Likelihood-Based Cointegration Analysis in Panels of Vector Error Correction Models. Journal of Business and Economic Statistics, 21, 295-318. doi: http://dx.doi.org/10.1198/073500103288618972

Gujarati, D. N., Porter, D. C. (2003) Basic Econometrics. 4th. New York: McGraw-Hill.

Gul, E., Ekinci, A. (2006) The causal relationship between the real exchange rate and export and import in Turkey: 1990-2006. Journal of Social Sciences, 16, 165183.

Gul, S., Sajid, M., Razzaq, N., Afzal, F. (2012) Agency cost, corporate governance and ownership structure (the case of Pakistan) International Journal of Business and Social Science, 3(9): 221-325.

Hamid, R., Yaqub, M. S., Awan, M. M. H. (2016) Antecedents of Dividend Policy: Empirical Evidence from Banking Sector of Pakistan. European Online Journal of Natural and Social Sciences, 5(2): 263-278.

Houston, J. F., Lin, C., Lin, P., Ma, Y. (2010) Creditor rights, information sharing, and bank risk taking. Journal of financial Economics, 96(3): 485-512.

Hsiao, C. (2014) Analysis of panel data: Cambridge university press.

Hyndman, R. J., Athanasopoulos, G. (2014) Forecasting: principles and practice: OTexts.

Ibrahim, M. (2016) Dividend Performance in the United Arab Emirates Banking Sector. International Journal of Finance Banking Studies, 5(6): 1.

Jiraporn, P., Kim, J. C., Kim, Y. S. (2011) Dividend payouts and corporate governance quality: An empirical investigation. Financial Review, 46(2): 251-279.

Karpavičius, S. (2014) Dividends: Relevance, rigidity, and signaling. Journal of Corporate Finance, 25, 289-312. 
M'rabet, R., Boujjat, W. (2016) The Relationship Between Dividend Payments And Firm Performance: A Study Of Listed Companies In Morocco. European scientific journal, 12(4): 469-482.

Magret, O. (2016) Capital Base and Operational Efficiency in Nigerian Deposit Money Banks (Evidence from a Two-Way Fixed Effect Approach) Global Journal of Management And Business Research, 16(1): 1-13.

Mahadevan, R., Asafu-Adjaye, J. (2007) Energy consumption, economic growth and prices: A reassessment using panel VECM for developed and developing countries. Energy Policy, 35(4): 2481-2490.

Maldajian, C., El Khoury, R. (2014) Determinants of the dividend policy: an empirical study on the Lebanese listed banks. International Journal of Economics and Finance, 6(4): 240-255.

Mizuno, M. (2007) Payout Policy of Japanese Firms: Analysis on the Survey of Four Industries Listed on the Tokyo Stock Exchange. Pacific Economic Review, 12(5): 631-650. doi: 10.1111/j.1468-0106.2007.00376.x

Mlachila, M., Dykes, D., Zajc, S., Aithnard, P.-H., Beck, T., Ncube, M., Nelvin, O. (2013) Banking in sub-Saharan Africa: Challenges and opportunities: Regional Studies and Roundtables, European Investment Bank (EIB)

Mougoué, M., Rao, R. P. (2003) The information signaling hypothesis of dividends: evidence from cointegration and causality tests. Journal of Business Finance Accounting, 30(3-4): 441-478.

Nnadi, M., Wogboroma, N., Kabel, B. (2013) Determinants of dividend policy: Evidence from listed firms in the African stock exchanges. Panoeconomicus, 60(6): 725741.

Odhiambo, N. M. (2014) Energy Dependence in Developing Countries: Does the Level of Income Matter? Atlantic Economic Journal, 42(1): 65-77. doi: 10.1007/s11293-0139402-2

Odunga, R., Nyangweso, P., Carter, D., Mwarumba, M. (2013) Credit Risk,"Capital Adequacy and Operating Efficiency Of Commercial Banks in Kenya". International Journal of Business and Management Invention, 2(9): 6-12.

Omran, M., Pointon, J. (2004) Dividend policy, trading characteristics and share prices: empirical evidence from Egyptian firms. International Journal of Theoretical and Applied Finance, 7(02): 121-133.

Onanjiri, R., Korankye, T. (2014a) Dividend Payout and Performance of Quoted Manufacturing Firms in Ghana. Research Journal of Finance and Accounting, 5(15): 442454.

Onanjiri, R., Korankye, T. (2014b) Dividend Payout and Performance of Quoted Manufacturing Firms in Ghana. Research Journal of Finance and Accounting, 5(15): 442-454.

Ouma, O. P. (2012) The relationship between dividend payout and firm performance: a study of listed companies in Kenya. European scientific journal, 8(9): 199-215.

Rubner, A. (1966) The economics of gambling: London, Macmillan.

Shao, L., Kwok, C. C., Guedhami, O. (2013) Dividend Policy: Balancing Shareholders' and Creditors' interests. Journal of financial Research, 36(1): 43-66.

Uddin, G. S., Shahbaz, M., Arouri, M., Teulon, F. (2014) Financial development and poverty reduction nexus: A cointegration and causality analysis in Bangladesh. Economic Modelling, 36, 405-412. 
Uwuigbe, U., Jafaru, J., Ajayi, A. (2012) Dividend policy and firm performance: A study of listed firms in Nigeria. Accounting and Management Information Systems, 11(3): 442-455.

Waseem, A., Saleh, A., Shukairi, M., Mahmood, N. (2011) The effect of dividend policy stability on the performance of banking sector listed on Amman Stock Exchange. International Journal of Humanities and Social Science, 1, 201-205.

Wolde-Rufael, Y. (2014) Electricity consumption and economic growth in transition countries: A revisit using bootstrap panel Granger causality analysis. Energy Economics, 44, 325-330.

Zhou, P., Ruland, W. (2006) Dividend payout and future earnings growth. Financial Analysts Journal, 62(3): 58-69. 